\title{
Bożena Dawidowicz
}

\section{Myślenie według wartości 0 "drugim" w filozofii Józefa Tischnera}

\section{Wprowadzenie}

Żyjemy w świecie, w którym ulegaja rozpadowi tak zwane wielkie narracje, czyli takie systemy światopoglądowe, które całościowo opisywały rzeczywistość, przewidując w niej dla człowieka solidnie uzasadnione miejsce. Taka narracja jest religia - dająca człowiekowi, przenikniętemu poczuciem osamotnienia i lęku, łączność z przekraczająca jednostkowość siłą, za której przyczyną możliwe staje się doznanie przeżycia duchowego. Współczesny człowiek, używając kategorii religijnych do spraw stricte ziemskich, często miesza te dwa porządki, co na głębszym poziomie odzwierciedla załamanie jego elementarnego zaufania do świata i ludzi. Przez co, i tu należy zastosować liczbę mnogą:

[...] stajemy się istotami coraz bardziej otępiałymi na drugich, coraz mniej rozumiejacymi drugich, coraz bardziej w ucieczce od ich konkretnych bólów ${ }^{1}$.

Bożena Dawidowicz (ORCID 0000-0003-4827-6535) - absolwentka Papieskiej Akademii Teologicznej w Krakowie, studiowała również filozofię teoretyczną na Wydziale Filozofii Chrześcijańskiej Katolickiego Uniwersytetu Lubelskiego oraz ukończyła Pomagisterskie Studium Dziennikarstwa na Wydziale Dziennikarstwa i Nauk Politycznych Uniwersytetu Warszawskiego. Uczestniczy w seminarium doktorskim Collegium Civitas, pracuje w Miejskim Ośrodku Kultury w Piotrkowie Trybunalskim.

1 J. Tischner, Myślenie według wartości, Wydawnictwo Znak, Kraków 2011, s. 402. 
Widocznym urzeczywistnieniem tego stanu jest powrót do żywota monadycznego, w którym każdy pozostaje zamknięty w swojej narracji i nieufnie nastawiony do drugiego. Przejawem tego jest pogłębiajacy się kryzys budowania prawdziwych relacji.

W artykule przedstawiam kilka refleksji o „drugim” ukazanym w świetle filozofii Józefa Tischnera, zwłaszcza jego filozofii dramatu. Moim celem jest oddanie istotnych właściwości myślenia filozofa o drugim poprzez wartości. Pozwoli to na rozwinięcie tezy, w myśl której spotkanie $z$ drugim wydarza się poprzez uczestnictwo w wartościach. $Z$ Tischnerowskiego myślenia według wartości o drugim można wynieść umiejętność stawiania źródłowych pytań dotyczących fundamentów ludzkiej egzystencji, szczególnie ważnych dla tych, którzy poszukuja prawdy o sobie oraz o drugim człowieku. To właśnie postawione tu pytanie - upominajace się o drugiego oraz o jego udział w spotkaniu $z$,ja” - wyrasta $z$ samej głębi egzystencjalnego doświadczenia człowieka. Drugi człowiek staje się pytaniem, które wymaga odpowiedzi. Szczególnie ważne jest to dziś dla człowieka żyjącego w świecie sprzecznych wartości, który poszukuje narracji spajającej jego zagubienie. Nie jest gotów na spotkanie $z$ drugim, wraca do „kryjówki” i okupuje się w swoim naturalnym egoizmie.

\section{Człowiek w centrum myśli Tischnera}

Przed przystapieniem do meritum należy dokonać wyboru przedmiotu, który w artykule zostanie poddany pogłębionej refleksji. Przede wszystkim trzeba zwrócić uwagę, że:

[...] perspektywa Tischnera wyklucza jakikolwiek inny przedmiot poza człowiekiem. Człowiek i specyficznie ludzkie doświadczenia [...] określaja przestrzeń badawcza jego filozofii ${ }^{2}$.

2 A. Siwek, Dobro a polityka. Platon $i$ Tischner. Dwie filozofie dobra, Instytut Studiów Politycznych Polskiej Akademii Nauk, Warszawa 2014, s. 100. 
Myśl filozoficzną Tischnera, będącą ważnym głosem w trwającym nieprzerwanie od wieków sporze o człowieka, należy zakotwiczyć

[...] w postawie afirmacji życia, świata i ludzi, która u swoich podstaw ma - pokrewną biblijnej idei - intuicję, że rzeczywistość jest w swej istocie darem Dobra. Filozofia ta jest $z$ gruntu antropologiczna, ponieważ jej centrum stanowi człowiek, wszelkie problemy rozważane sa $z$ perspektywy filozofii człowieka, a antropologia filozoficzna ma głębszy sens niż tylko zaspokajanie ciekawości poznawczej - jej misja jest pomóc człowiekowi w samorozumieniu, byciu soba i w mądrzejszym sposobie bycia ${ }^{3}$.

Wyjątkowa na tym tle jest Tischnerowska propozycja wizji człowieka osadzona we współczesnej filozofii chrześcijańskiej, rozumiana jako filozofia dramatu, w której szczególnie istotnym wątkiem jest otwarcie dialogiczne na drugiego. Inspiracje dla koncepcji drugiego zostały zatem zaczerpnięte ze sfery myślenia religijnego, czego przejawem jest:

[...] duchowy, to znaczy międzyosobowy charakter przekazu chrześcijańskiego, dla którego trzeba szukać kategorii filozoficznych, przede wszystkim z dziedziny dialogu między osobami, między duchowymi, myślącymi i miłującymi się podmiotami ${ }^{4}$.

Implikuje to określony typ myślenia autora Filozofii dramatu, który nawiąuje „dialog $z$ fenomenologia, myśla Heideggera, egzystencjalizmem i hermeneutyka, a przede wszystkim $z$ filozofia spotkania"5. Jego głębsze odsłonięcie, na poziomie duchowości, dokonuje się natomiast w wymiarze aksjologicznym ukierunkowanym agatologicznie oraz w wymiarze dialogicznym, w rozpoznaniu hierarchii wartości i urzeczywistnieniu jej w praktyce, w spotkaniu człowieka $z$ drugim człowiekiem. Zamysł ten wspiera się na przeświadczeniu fundamentalnym dla filozofii dialogu - że:

\footnotetext{
3 J. Galarowicz, Paradoks egzystencji etycznej. Inspiracje: Ingarden - Wojtyła - Tischner, Wydawnictwo Naukowe Papieskiej Akademii Teologicznej, Kraków 2009, s. 320-321.

4 K. Tarnowski, „Myślenie według wartości” Józefa Tischnera, „Znak” 1985, nr 12 (373), s. 35 .

5 J. Galarowicz, Paradoks egzystencji etycznej..., s. 255.
} 
[...] nie sposób zrozumieć człowieka, pomijając jego wymiar dialogiczny i międzyosobowe relacje, w jakie wchodzi ${ }^{6}$.

W trakcie spotkania dochodzi do twórczego działania wzajemności. Jej sens zawiera się w relacji ja-drugi. Jak zauważa Tischner:

[...] człowiek jest dla Kogoś. Nie żyjemy dla siebie. Dla kogo jest człowiek? Tego człowiek dokładnie nie wie [...]. Wiadomo tylko, że dla... Jest muzyka, która traci swój sens, gdy jej nikt nie słyszy. Człowiek nie zatraca się jednak w swoim dla. Dzięki byciu dla... staje się soba. Muzyka tym bardziej zachwyca, im bardziej jest muzyka ${ }^{7}$.

W ten sposób filozof wychodzi poza materialną rzeczywistość, nadając antropologiczno-etycznym intuicjom skupionym wokół człowieka oryginalna formę i treść.

Tischner patrzy na człowieka $z$ perspektywy agatologicznej i dialogicznej:

Myśleć o człowieku znaczy przede wszystkim rozumieć go jako istotę egzystujaca wobec dobra oraz wobec innych ludzi ${ }^{8}$.

U podstaw jego filozofii człowieka tkwi: intuicja - idea o charakterze biblijnym, że człowiek jest przede wszystkim dobrem, i to dobrem szczególnym („bardzo dobre było”)

Zgłębianie prawdy o człowieku jest u Tischnera mocno osadzone w doświadczeniu i w tym sensie możemy mówić o nim jako o fenomenologu. Człowiek jawi się w jego rozważaniach jako rzeczywistość dynamiczna i dramatyczna. Prawdy o człowieku doszukuje się w „ja dialogicznym i dramatycznym, a mówiąc lepiej - w osobie jako istocie dialogicznej i dramatycznej, podmiocie, dla którego istoty i losu doniosłe znaczenie ma spotkanie i obcowanie $z$ drugim człowiekiem i $z$ Bogiem oraz uczestniczenie w dramacie dobra i zła"10. Jak podkreśla Jan Galarowicz, dobro to starał się Tischner odsłonić,

\footnotetext{
Ibidem, s. 323.

J. Tischner, Filozofia dramatu, Wydawnictwo Znak, Kraków 1999, s. 232-233.

A. Siwek, Dobro a polityka..., s. 115.

J. Galarowicz, Paradoks egzystencji etycznej..., s. 321.

10 Ibidem, s. 307.
} 
opisać i wysłowić, ukazując przenikająca go wolność oraz odpowiedzialność, jego dialogiczny charakter, jego zagrożenie przez zło, jego dramat $z$ człowiekiem oraz jego dynamikę ${ }^{11}$. W takim ujęciu człowiek jest „egzystencja dramatyczna, podmiotem dramatu, w którym stawka jest jego ocalenie przez dobro lub zniszczenie, unicestwienie, potępienie przez zło"12.

Tym, co wzywa do myślenia był dla Tischnera drugi człowiek ${ }^{13}$. Choć moje rozważania będa skupione głównie wokół drugiego, to należy wyjść od „ja”, będącego podmiotem Tischnerowskiej filozofii dramatu, dla której fundamentalną sprawa jest wydarzenie spotkania ${ }^{14}$. Wypływa to $z$ następującej refleksji: jeśli nawet napotkamy drugiego, spotkanie może nie nastapić. „Ja” może przejść obok. Podobnie „ty” może przejść obojętnie obok „mnie”. Barbara Skarga podkreśla, że Tischnerowski podmiot dramatu to człowiek agatologiczny, czyli skoncentrowany na fundamentalnej wartości, jaka jest dobro ${ }^{15}$. Dodaje, że Tischner, mówiąc o agatologii, ma na myśli rodzaj antropologii:

[Tischner] Zaczął niegdyś od „myślenia wokół wartości”, tu chciałby myśleć wokół dobra. Tego rodzaju myślenie, niejednokrotnie uciekające się do fenomenologicznej metody, nie zobowiązuje do żadnej systematyki, staje się swobodna refleksja, czasem bardziej sugestywna niż wszelkie uczone wywody. To nie znaczy, że jej brak konsekwencji [...] jest, być może, jedynym sposobem mówienia o kwestiach nieprzejrzystych, tak różnych i zmiennych w ludzkich doświadczeniach i niepoddających się ścisłemu upojęciowieniu ${ }^{16}$.

Najodpowiedniejsza płaszczyzna rozważań antropologicznych stały się dla Tischnera filozofia dramatu i agatologia. Przedstawiany przez niego człowiek:

11 Ibidem, s. 313.

12 Ibidem, s. 316-317.

13 Zob. np. D. Kot, Posłowie, w: J. Tischner, Inny. Eseje o spotkaniu, Wydawnictwo Znak, Kraków 2017, s. 93-94.

14 Zob. np. S. Szary, Człowiek - podmiot dramatu. Antropologiczne aspekty filozofii dramatu Józefa Tischnera, Wydawnictwo Antyk, Kęty 2005, s. 60.

15 B. Skarga, Człowiek agatologiczny, w: Pytajac o człowieka. Myśl filozoficzna Józefa Tischnera, red. W. Zuziak, Wydawnictwo Znak, Kraków 2002, s. 99-112.

16 Ibidem, s. 99-100. 
[...] będąc swoistą wartościa, osobliwym dobrem - ja aksjologicznym czy ja agatologicznym, staje się dobrem dialogicznym i podmiotem międzyosobowego dramatu - istota otwarta na inne osoby, zdolna do spotkania i wchodząca $z$ nimi w różnorodne relacje ${ }^{17}$.

W człowieku widział Tischner szczególną wartość czy też swoiste dobro, które w pełni dojrzewa w dramacie:

Człowiek „bardziej jest”, gdy bardziej staje się dobrym, „jest mniej” i zapada w „nicość” [...] gdy staje się złym ${ }^{18}$.

Przy czym dodawał, że:

Nikt nie może być dobry w samotności. I nikt nie może być dobry z konieczności. [...] Nie tylko dlatego, że aby być dobrym, trzeba być dobrym „dla kogoś”, ale również dlatego, iż aby być dobrym, trzeba wiedzieć, że i jak się jest dobrym ${ }^{19}$.

Oznacza to, iż dobro i zło rodzą się w przestrzeni międzyosobowej, a ściślej mówiąc: przychodzą od drugiego. Potwierdza to Tischner w jednej ze swoich wypowiedzi:

[...] gdy chodzi o doświadczenie dobra i zła, źródłem jest doświadczenie drugiego człowieka ${ }^{20}$.

Wskazuje to na dialogiczny charakter osoby. W ujęciu Tischnera jest to ja aksjologiczne $\mathrm{w}$ dialogu ${ }^{21}$. A to $\mathrm{z}$ kolei implikuje fakt, że gdyby nasza natura była monadyczność, nie ciążłłaby nam samotność. Osoba w ujęciu Tischnera jest bowiem „podmiotem i uczestnikiem dramatu - dramatu jaki rozgrywa się między nim [...] a drugim człowiekiem"22.

\footnotetext{
17 J. Galarowicz, Paradoks egzystencji etycznej..., s. 309.

18 J. Tischner, Zarys filozofii człowieka dla duszpasterzy i artystów, Wydawnictwo Naukowe Papieskiej Akademii Teologicznej, Kraków 1991, s. 121.

19 J. Tischner, Spór o istnienie człowieka, Wydawnictwo Znak, Kraków 1998, s. 343.

20 Człowiek jest istota dramatyczna. Rozmowa z ks. prof. Józefem Tischnerem, w: C. Wodziński, Filozofia jako sztuka myślenia, Wydawnictwo Prószyński i S-ka, Warszawa 2000, s. 109.

${ }_{21}$ J. Tischner, Myślenie w żywiole piękna, Wydawnictwo Znak, Kraków 2004, s. 68.

22 J. Galarowicz, Paradoks egzystencji etycznej..., s. 317.
} 
Tischnerowska koncepcja człowieka, co trzeba podkreślić, „jest $\mathrm{w}$ istocie oryginalna filozofia osoby - agatologicznym personalizmem dialogicznym”23. Jak zauważa Jan Galarowicz: „Osoba w ujęciu tego myśliciela ma mocna strukturę egologiczna (jest byciem-dla-siebie) i zarazem jest istota o charakterze dialogicznym"24. Zanim Tischner ostatecznie doszedł do takiego stanowiska, to na pewnym etapie kształtowania swoich poglądów „pod wpływem Lévinasa, zbliżył się do klasycznego podejścia dialogiki, które głosi prymat intersubiektywności lub pierwszeństwo ty wobec ja, czego dowodem jest przede wszystkim Filozofia dramatu"25. Właśnie dzięki dialogicznej strukturze osoby możliwe jest przede wszystkim autentyczne spotkanie człowieka $z$ drugim człowiekiem. Wrażliwość na drugiego człowieka, która znalazła wyraz w dziele myśliciela.

\section{Spotkanie z „drugim”}

Myśl filozoficzna Tischnera jest wyrazem refleksji wyrosłej z doświadczenia spotkania. Wypływa $z$ wnętrza metafory „spotkania na drodze":

Na drodze spotyka się ze sobą dwoje ludzi, idących w różnych kierunkach, i jeden $z$ nich pyta: „Dokad prowadzi droga?”. Drugi odpowiada i rozchodzą się, każdy w swoją stronę ${ }^{26}$.

Metafora „spotkania na drodze” wynika, zdaniem Tischnera, $z$ fenomenologicznych poszukiwań doświadczeń źródłowych, do których należy przede wszystkim doświadczenie drugiego człowieka:

Źródło jest na początku wszystkiego. Ono daje początek rzece, która może mieć rozmaite rozgałęzienia, woda rzeki może służyć do wykonywania roz-

\footnotetext{
Ibidem, s. 321.

24 Ibidem.

25 Ibidem, s. 324.

26 Spotkanie. $Z$ ks. Józefem Tischnerem rozmawia Anna Karoń-Ostrowska, Wydawnictwo Znak, Kraków 2003, s. 128.
} 
maitych prac. Tak samo spotkanie $z$ drugim jest na poczatku wszelkiego doświadczenia świata. Można powiedzieć, że drugi jest kategorią a priori, dzięki której możliwy jest tak zwany obiektywny świat ${ }^{27}$.

Dla krakowskiego filozofa spotkanie $z$ drugim jest zatem początkiem myślenia. Podstawowe nie jest jednak samo doświadczenie spotkania Ja i Ty, ale samo Ja, czyli podmiot spotkania $z$ jego wewnętrzną przestrzenią ja aksjologicznego. Tischner podkreślał:

Posługuję się szeroko pojętą metodą analizy transcendentalnej. Wygląda to tak: najpierw szukamy doświadczenia źródłowego (w tym wypadku jest to spotkanie na drodze), a kiedy mamy już to źródło, trzeba do opisu doświadczenia dodać pytanie: jak musi być zbudowana ziemia, żeby mogło z niej wypłynać źródło. Otóż źródłem jest spotkanie, a ziemia jest podmiot - spotykajacy. Pytam o to, jak musi być zbudowany, żeby mógł spotkać drugiego. Pytam o ja, o rozmiar jego duszy, o to, jak widzi, co słyszy, pytam o doświadczenie dobra i zła w nim, pytam o ja aksjologiczne i agatologiczne"28.

Tischnerowska filozofia człowieka określana jest również jako filozofia ludzkiego dramatu. Nie chodziło mu jednak o „osiągnięcie precyzji pojęciowej” słowa „dramat”. Jest to, jak pisał, „cel drugorzędny”. „Celem pierwszorzędnym” jest natomiast:

[...] przywrócenie słowu „dramat” właściwego ciężaru gatunkowego. Można to osiagnąć jedynie przez wskazanie treści, na którą słowo to bezpośrednio lub pośrednio intencja swoja wskazuje. Trzeba posłużyć się słowem jako pomostem do rzeczy. Trzeba spytać: na jaką rzeczywistość, na co słowo wskazuje? Cokolwiek by się rzekło, wskazuje ono na życie człowieka. Rozumieć dramat to zrozumieć, że człowiek jest istota dramatyczna. Dokonując krok po kroku rozjaśnienia ludzkiej egzystencji jako egzystencji dramatycznej, przywracamy pojęciu dramatu właściwy sens ${ }^{29}$.

Jak pisał Tischner, człowiek nie byłby egzystencją dramatyczna, gdyby nie trzy podstawowe kategorie: otwarcie na innego człowieka, otwarcie na scenę dramatu i przepływający czas ${ }^{30}$. Czas dany czło-

27 Ibidem, s. 129.

28 Ibidem, s. 132.

29 J. Tischner, Filozofia dramatu..., s. 7.

so Ibidem, s. 8. 
wiekowi - pozbawiony obiektywności i linearności - staje się „czasem dramatycznym”. Jest to czas, który dzieje się między „uczestnikami jednego i tego samego dramatu" i wiąże ich ze scena, na której ów dramat się rozgrywa:

Ma on własna - sobie tylko właściwa - logikę, która rządzi jego ciagłościa i nieodwracalnościa. Coś musi się najpierw stać, by coś innego mogło stać się potem. We wszystkim, co staje się potem, znać ślad tego, co było przedtem. Logiki tej nie można odwrócić. Można wrócić na opuszczone miejsce, można odwołać słowo wypowiedziane nie w porę, ale nie można cofnać czasu, który płynie między nami. Ciagłość naszego czasu jest jakby substancja dramatu ${ }^{31}$.

Świat doświadczalny, w którym człowiek egzystuje, zostaje określony przez Tischnera jako „scena dramatu”. Co oznacza, że:

[...] nie można oddzielić sposobów doświadczania świata od sposobów doświadczania ludzi, a przede wszystkim od sposobów przeżywania dramatu człowieka z człowiekiem. Człowiek znaczy ziemię śladami, które świadczą o spotkaniach, obcowaniach, rozstaniach $z$ innymi ${ }^{32}$.

Człowiek czyni sobie ziemię poddana poprzez akt intencjonalnej obiektywizacji: „doświadcza sceny, uprzedmiotawiajac ja”33. Jednocześnie, na co zwraca uwage Tischner, doświadczenie ziemi jako sceny jest zapośredniczone przez dialog człowieka $z$ człowiekiem:

Być na ziemi znaczy: dotykać jej poprzez płacz i uśmiech drugiego ${ }^{34}$.

Innego więc, niż otwarcia właściwego świadomości intencjonalnej, wymaga otwarcie na drugiego jako uczestnika dramatu:

Inny człowiek staje wobec mnie poprzez jakieś roszczenie, w którego następstwie powstaje we mnie poczucie zobowiazania. Świadomość tego, że drugi jest obecny, dopełnia się jako świadomość roszczenia - roszczenia,

\footnotetext{
Ibidem.

Ibidem, s. 220.

Ibidem, s. 9.

34 J. Tischner, Zło $w$ dialogu kuszenia, „Znak” 1982, nr 3 (328), s. 11.
} 
które zobowiazuje. Oto do moich uszu dochodzi twoje pytanie. Jest chwila ciszy, wspólnej teraźniejszości. Oczekujesz na odpowiedź. Trzeba dać odpowiedź. To „trzeba” jest istotne. Dzięki niemu i w nim jesteś przy mnie obecny"35.

\section{Dlatego też:}

[...] człowiek żyje w ten sposób, że bierze udział w dramacie - jest istota dramatyczną. Inaczej żyć nie może. Jego natura jest dramatyczny czas i dwa otwarcia - intencjonalne otwarcie na scenę i dialogiczne otwarcie na innego człowieka. Być istota dramatyczna znaczy: istnieć w określonym czasie i w określony sposób otwierać się na innych i na świat - scenę ${ }^{36}$.

Głównym wątkiem Tischnerowskiego myślenia o człowieku jest „doświadczenie drugiego, innego"37. Człowiek jako istota dramatyczna:

[...] może nie wiedzieć, na czym polega ostatecznie jego zguba i na czym polega jego ocalenie, pomimo to może mieć świadomość, że o coś takiego właśnie w życiu chodzi. Będąc przekonany, że zguba i ocalenie sa w jego rękach, człowiek kieruje swym życiem wedle tego przeświadczenia ${ }^{38}$.

Może więc siebie zatracić lub może siebie potwierdzić, co ma u Tischnera istotny zwiąek $z$ dialogicznym otwarciem na drugiego, spotkaniem drugiego w drodze:

Spotkać znaczy coś więcej i coś innego niż zobaczyć, usłyszeć, podać rękę. Co znaczy spotkać? Spotkać to osiagnąc bezpośrednia naoczność tragiczności przenikającej wszystkie sposoby bycia Drugiego ${ }^{39}$.

Poznanie drugiego, co wyraźnie podkreśla Tischner, od samego początku musi uwzględniać fakt, że drugi ma świadomość bycia badanym, a „będąc poddanym wymogom prawdy, może się przed poznającym zamknać lub otworzyć [...] może również konfrontować

35 J. Tischner, Filozofia dramatu..., s. 9.

36 Ibidem, s. 10.

37 A. Siwek, Dobro a polityka..., s. 105.

38 J. Tischner, Filozofia dramatu..., s. 10.

39 J. Tischner, Myślenie według wartości..., s. 533. 
uzyskane o nim poznanie $z$ własnym wewnętrznym doświadczeniem"40. Dokonując uproszczonego przeglądu koncepcji poznawczego obcowania $z$ drugim, krakowski filozof zajmuje stanowisko pomiędzy przeciwstawnymi poglądami Edmunda Husserla a tymi, które prezentuja na przykład Max Scheler, Martin Buber czy Gabriel Marcel ${ }^{41}$. Wyraża się ono w tym, że filozof nie powtarza za Husserlem drogi „transcendentalnego subiektywizmu” (od Ja do Ty) ani też drogi przeciwnej „genetycznego obiektywizmu” (od Ty do Ja). Proponuje natomiast model pośredni, który wyraża formuła: „wiem, że mnie rozumiesz, więc jesteśmy". Wychodzi od apodyktycznych danych refleksji Husserla, nie zatracajac jednak stanowiska przeciwnego, a jednocześnie unikając ich skrajności:

Świadomość „jesteśmy” budzi się w dialogu z drugim, w konfrontacji spojrzeń, w sporze i jednoczesnym dążeniu do zgody, w których inicjatywa i oświecenie przychodzą często od drugiego ${ }^{42}$.

Tischner pyta następnie o to, co jest głównym czynnikiem syntetyzującym wszelkie możliwe sposoby doświadczania i poznania drugiego. Odwołuje się w pierwszej kolejności do fenomenu języka i koncentruje na „elementarnych zjawiskach językowych związanych $z$ idea poznawania drugiego" ${ }^{43}$. Imię identyfikuje osobę, co więcej, wydobywa na jaw obecność indywidualnej wartości ludzkiej

\footnotetext{
40 J. Tischner, Filozofia dramatu..., s. 273.

41 Tischner podzielił najbardziej znane koncepcje obcowania $z$ drugim na dwie grupy: „Jedni - jak np. Husserl - sądzą, że właściwym punktem wyjścia badań jest subiektywna aktywność podmiotu poznającego, w szczególności świadomość Ja transcendentalnego, pozaświatowego, konstytuującego sens świata i sens drugiego jako istoty podobnej do mnie, bytujacej w owym świecie. Taki punkt wyjścia badań gwarantuje apodyktyczność, czyli niepowatpiewalność $\mathrm{w}$ ich rezultaty. $Z$ tego rodzaju decyzja teoriopoznawcza idzie $\mathrm{w}$ parze określona koncepcja drugiego. Drugi człowiek pojawia się tutaj jako inne-ja, czyli alter-ego: najpierw obcujemy sami ze soba, $z$ naszym ja, następnie według wiedzy o ja zawartej w tym obcowaniu rozpoznajemy drugiego jako ty (ja-inne). Wiem, że drugi jest i jest drugim, bo wiem, że ja jestem. Ale inni, np. Scheler, Buber, Gabriel Marcel, sa przeciwnego zdania. Ty nie jest innym ja lecz raczej moje-ja jest innym -ty. U początków pochodzenia świadomości ja leży obecność ty, a być może nawet obecność ogólniejszego my. Dopiero w dialogu, w sporze, w opozycji, a także w daż̇eniu do nowej wspólnoty tworzy się świadomość mojego ja jako istoty samoistnej, odrębnej od drugiego. Wiem, że ja jestem, bo wiem, że drugi jest". Ibidem, s. 271-272.

42 Ibidem, s. 273.

43 Ibidem, s. 270.
} 
i - będąc pewnym początkiem wtajemniczenia - dokonuje tego, iż otwiera przed człowiekiem szczególny horyzont sensu, w ramach którego może się rozwijać dalsze poznawcze obcowanie człowieka $z$ człowiekiem. Obcujacc $z$ drugim poprzez jego imię, wyzwalamy się spod presji modeli reifikujacych i wchodzimy w bogaty świat wartości typowo ludzkich. Dokonuje się to „w horyzoncie imiennym sensu" ${ }^{44}$, a także w przestrzeni sensu współdzielonej $z$ drugim. W swym zasadniczym rdzeniu, na co wskazuje Tischner, przestrzeń jawi się przede wszystkim jako pole sensownej wolności człowieka ${ }^{45}$. Miejsce wspólnej $z$ drugim przestrzeni sensu nie jest jednak czymś zewnętrznym w stosunku do człowieka, ale stanowi prawdziwe odbicie jego twarzy. Jest istotnym czynnikiem kształtujaccym sposób istnienia wśród innych. Główną rolę w tym procesie filozof przypisuje „przestrzeni poznawczego obcowania $z$ drugim”. Jak twierdzi:

[...] organizacja owej przestrzeni jest podstawa porządku wszystkich możliwych orzeczeń określajacych to, czym człowiek jest. [...] Organizacja wynika $[\ldots] \mathrm{z}$ bardziej podstawowego niż doświadczenie przestrzeni doświadczenia wartości ${ }^{46}$.

Dlatego też, jak pisze dalej, bez elementarnych danych aksjologicznych rozumienie człowieka nie jest możliwe. Formy możliwego obcowania $z$ drugim sa wyznaczone przez strukturę imiennej przestrzeni sensu, w której:

[...] wyróżniamy najpierw pole obecności człowieka dla człowieka, które nazwiemy krótko miejscem, oraz pola obcowań, w obrębie których spotykamy się z drugim jako naszym współpracownikiem, przeciwnikiem, władającym nami lub nam poddanym ${ }^{47}$.

Nawet religijna sfera obcowań człowieka $z$ Bogiem, co podkreśla filozof ${ }^{48}$, nosi na sobie strukturalne piętno przestrzeni między-

\footnotetext{
Ibidem, s. 278.

Ibidem, s. 284.

46 Ibidem, s. 271.

47 Ibidem, s. 291.

48 Ibidem, s. 292.
} 
ludzkiej - imiennej. Do opisu podstawowych odniesień człowieka do człowieka szczególne znaczenie ma słowo „wobec”. Jest ono, zdaniem Tischnera, określeniem stosunku bytów świadomych siebie nawzajem ${ }^{49}$. Wskazuje też „na jakąś przestrzeń: być wobec, znaczy być dostatecznie blisko, by nie zgubić drugiego $z$ pola widzenia, ale zarazem być na tyle daleko, by go nie zatracić [...]"50 w żywym, bezpośrednim kontakcie.

Doświadczenie spotkania jest zatem:

[...] czymś więcej niż zwyczajnym „zetknięciem się” z drugim, widzeniem czy słyszeniem drugiego. Spotkanie to Wydarzenie. Od spotkania zaczyna się dramat, którego przebiegu nie da się przewidziećc ${ }^{51}$.

O spotkaniu można mówić jako o doświadczaniu drugiego oraz o składaniu przed nim świadectwa:

Ten, kto spotyka, wykracza - transcenduje - poza siebie w podwójnym sensie tego słowa: ku temu, komu może dać świadectwo (w stronę innego), i ku temu, przed kim może złożyć świadectwo (przed Nim - tym, który żąda świadectwa). Dlatego należy powiedzieć: spotkać to do-świadczyć Transcendencji52.

Spotkanie ma zatem misję transcendentna.

Człowiek łączy się $z$ człowiekiem za pośrednictwem dialogu, w którym główna rola przypada pytaniom i odpowiedziom. Pytam i oczekuję odpowiedzi. Spotkanie odsłania, w sposób metaforyczny i skondensowany, wage pytania. Jest przede wszystkim podstawowym sposobem otwarcia, wskazującym jednoznacznie na dialogiczność podmiotu, rozumianą również jako „obecność dialogiczna". Zdaniem Tischnera jest to czas takiej teraźniejszości, w której pytający czeka na odpowiedź, a zapytany wciąż jej jeszcze nie udziela ${ }^{53}$. Wygląda to następująco:

49 Ibidem, s. 286.

so Ibidem.

51 J. Tischner, Myślenie według wartości..., s. 533.

52 J. Tischner, Filozofia dramatu..., s. 27.

53 Ibidem, s. 99. 
Najpierw drugi staje wobec mnie, dopiero potem ewentualnie sam staję wobec drugiego. Drugi patrzy na mnie, widzi mnie, mówi do mnie. Jestem „zagadnięty” przez drugiego, jestem „ugodzony” jego „wymownym spojrzeniem”, urażony „nieopacznym słowem”, pociagnięty „wezwaniem”. Drugi to prawdziwy transcendens. Pierwotnym transcendowaniem jest uobecnienie ${ }^{54}$.

W zasadzie to „pytania sa oknami monady"55, która wychodzi ze swego bycia dla siebie i otwiera się na to, co inne. Pytanie, zdaniem Tischnera, „rozbija zamknięty, monadyczny świat podmiotu”56. Każde pytanie stwarza możliwość przeniesienia się ze świata jednego człowieka w świat drugiego:

Odpowiadając na pytanie, zaczynam być - o ile odpowiadam na pytanie „dla kogoś". Innymi słowy: staję się odpowiedzialny. Istotny sens pytania polega na tym, że budzi ono w zapytanym poczucie odpowiedzialności ${ }^{57}$,

Jest to już odniesienie do sfery etycznej. Dlatego też, aby właściwie wyjaśnić rodowód odpowiedzi na pytanie:

[...] trzeba porzucić obszary ontologii i logiki, a wkroczyć w obszar metafizyki dobra. Jednakże metafizyka dobra jest ściśle związana $z$ metafizyka zła. Domyślamy się więc, że u źródeł odpowiedzi na zadane człowiekowi pytanie musi być jakiś wybór etyczny - wybór między dobrem a złem. Odpowiadający nie tylko daje odpowiedź innemu, ale daje ją również sobie - sobie jako uczestnikowi dramatu dobra i zła $^{58}$.

Wymiar agatologiczny jest zatem szczególnie istotnym obszarem opisu fenomenu spotkania. Pytanie prowokuje do odpowiedzi, otwiera ludzi na siebie, przestaja być monadami zamkniętymi we własnej narracji, podejrzliwie nastawionymi do tego, co przychodzi $z$ zewnattrz. Ostatecznie w reakcji na pytanie pojawia się odpowiedź:

Po pytaniu i po odpowiedzi - w ogóle po rozmowie - nie jesteśmy już tacy sami, jak byliśmy przedtem. Coś sobie zawdzięczamy. O coś siebie może-

\footnotetext{
Ibidem, s. 287.

S. Szary, Człowiek - podmiot dramatu..., s. 95.

Spotkanie..., s. 136.

7 J. Tischner, Filozofia dramatu..., s. 90.

58 Ibidem, s. 90-91.
} 
my obwinić. Czym jest wzajemność? Wzajemność oznacza, że jesteśmy, jacy jesteśmy, poprzez siebie. To „poprzez” oznacza: możemy siebie obwiniać lub możemy być sobie wdzięczni ${ }^{59}$.

W ten sposób Tischner przekracza filozofię samotnego podmiotu i wychodzi na spotkanie człowieka $z$ drugim człowiekiem. Anna Siwek, analizując doświadczenie spotkania, pisze także o sytuacjach „[...] uniemożliwiających prowadzenie dialogu, zamykających możliwość spotkania. Relacja władzy, postawa potępienia i kłamstwa - oto główne przeszkody, które łączy jedno: zatracenie perspektywy agatologicznej"60.

Tischner nie był zwolennikiem skrajnego indywidualizmu w rozumieniu monadyzmu. Nie pojmował zatem człowieka jako czystej monady. Widział w nim istotę otwarta na sferę wartości przedmiotowych (relacyjność intencjonalna) oraz na drugiego człowieka (relacyjność dialogiczna), kładąc przy tym wyraźny akcent na jego strukturę egologiczną. Postawa dialogiczna - w przeciwieństwie do postawy intencjonalnej - wyklucza uprzedmiotowienie:

Dopiero w dialogu, w sporze, w opozycji, a także w dążeniu do nowej wspólnoty tworzy się świadomość mojego ja jako istoty samoistnej, odrębnej od drugiego. Wiem, że ja jestem, bo wiem, że drugi jest ${ }^{61}$.

Drugi jawi się jako podmiot, inny, inne ja:

Otwarcie na innego ma charakter dialogiczny. Różni się ono istotnie od otwarcia intencjonalnego. Dzięki otwarciu intencjonalnemu staje przed nami świat przedmiotów, dzięki otwarciu dialogicznemu stajesz przy mnie Ty ${ }^{62}$.

Jan Galarowicz podkreśla, że:

O ile przedmiot intencjonalności jest elementem świata, w relacji dialogicznej inny wykracza poza świat przedmiotowy. $Z$ intencjonalnością wią̇e

59 Ibidem, s. 106.

60 A. Siwek, Dobro a polityka..., s. 110.

61 J. Tischner, Filozofia dramatu..., s. 272.

62 Ibidem, s. 9-10. 
Tischner horyzont wyglądów, a $z$ dialogicznościa - horyzont twarzy: przedmiot, rzecz się zjawia, natomiast człowiek wyraża się poprzez twarz ${ }^{63}$.

Tischner wyraża to następująco:

[...] poznawany przedmiot (rzecz) nie ma świadomości tego, iż jest poznawany, natomiast poznawany człowiek może mieć i ma taką świadomość. Dla przedmiotów prawda ich istnienia nie jest ich problemem, tymczasem dla człowieka stanowi ona podstawowe zagadnienie jego życia ${ }^{64}$.

Doświadczenie twarzy - oraz płynące $z$ niej wezwanie do wzajemności - warunkuje spotkanie $z$ drugim. Tischner wprowadza tę kategorię do Filozofii dramatu. Nawiązuje w ten sposób do antropologii Emmnuela Lévinasa, u którego:

Pojęcie twarzy pozwala [...] opisać bezpośredniość. [...] bezpośredniość jest wezwaniem [...]. Bezpośrednie jest tylko spotkanie twarza w twarz ${ }^{65}$.

Z kolei to, co różni obu myślicieli w sposobie opisywania fenomenu twarzy, widoczne jest w odpowiedziach, których udzielaja na pytanie: Do czego wzywa twarz drugiego? Tischner pisał:

U Lévinasa ważny jest moment etyczny - to, że odpowiadam i dlaczego odpowiadam. U mnie ten moment też jest ważny, ale nie najistotniejszy. Dla mnie podstawowe jest to, że drugi jest poczatkiem myślenia. [...] U mnie pierwsza jest etyka myślenia. Drugi mówi: Nie kłam. To jest ciagły konflikt ze złośliwym geniuszem, którego opisał Kartezjusz ${ }^{66}$.

Według Tischnera twarz wzywa nie tylko do etyki, jak chciał Lévinas, ale także do „powiedzenia prawdy”. Co więcej:

Cała etyka bez tego pytania - kto jest moim bliźnim? wisi w próżni ${ }^{67}$.

J. Galarowicz, Paradoks egzystencji etycznej..., s. 326.

64 J .Tischner, Filozofia dramatu..., s. 272.

65 E. Lévinas, Całość i nieskończoność. Esej o zewnętrzności, tłum. M. Kowalska, Wydawnictwo Naukowe PWN, Warszawa 1998, s. 43.

66 Spotkanie..., s. 130.

67 Ibidem. 
Dlatego też:

[...] trzeba otworzyć się na wymiar myślenia, na wymiar prawdy, na obiektywizm ${ }^{68}$.

Z kolei za sprawa intencjonalnego otwarcia, o którym wspomniałam wcześniej, człowiek codziennie na nowo odkrywa scenę, na której nieprzerwanie trwa akcja dramatu. Świadomość dialogiczna otwiera człowieka na tę przestrzeń, w której czas wydaje się decydujący w rozgrywającym się między osobami dramacie:

Ten dialogiczny rodzaj otwartości umożliwia człowiekowi istnienie osobowe, agatologiczne i dialogiczne, a więc dramatyczne ${ }^{69}$.

Pozwala - co stanowi istotę prowadzonych tu rozważań - na doświadczenie drugiego w jego inności, spotkanie go na drodze życia. W sposobach obcowania $z$ nim wysuwa się na pierwszy plan zasada „Pozwolić drugiemu być”.

Spotkanie $z$ drugim jest wydarzeniem, które za każdym razem „otwiera przed spotkanym i spotykającym nowy wątek dramatyczny"70. Ważnym następstwem tego wydarzenia, na co zwraca uwagę Tischner, jest zmiana znaczenia przestrzeni, która zaczyna przypominać skrzyżowanie dróg poprzecinane różnymi możliwościami: można się zwrócić ku spotkanemu lub się od niego odwrócić, także wywyższenie i poniżenie sa odmianą ruchu „od-do" ${ }^{11}$. W samym środku tego ruchu znajduje się człowiek, dając sobie prawo do czucia życia, wyrażania emocji i przeżywania ich. Wraz z przestrzenia konstytuuje się czas możliwego obcowania $z$ drugim, innym:

Przestrzeń staje się sceną dramatu, a czas jego wewnętrznym rytmem ${ }^{72}$.

Należy raz jeszcze podkreślić, że spotkanie $z$ drugim:

\footnotetext{
Ibidem.

J. Galarowicz, Paradoks egzystencji etycznej..., s. 328.

J. Tischner, Inny..., s. 5.

Ibidem, s. 5-6.

72 Ibidem, s. 6.
} 
[...] wydarza się i dopełnia na płaszczyźnie dialogicznej, różnej od płaszczyzny intencjonalnej. Płaszczyzna intencjonalna to płaszczyzna aktualnych lub możliwych „uprzedmiotowień” [...]. Ale inny nie jest rzeczą między rzeczami ani przedmiotem między przedmiotami, lecz podmiotem, innym $\mathrm{Ja}[\ldots]^{73}$.

Warto w tym miejscu, za Tischnerem, przytoczyć odmienne w tym względzie stanowisko, które zakłada, że obie analizowane płaszczyzny można uznać za:

[...] dwa aspekty tego samego aktu - jeden zakłada drugi, jeden drugi przenika. Inny człowiek nie jest moim przedmiotem i ja nie jestem jego przedmiotem. Ale to nie znaczy, że nie możemy siebie uprzedmiotowić, jak głosił Jean-Paul Sartre. Nie jest również wykluczone dialogiczne odniesienie do sceny. Na tym właśnie polega wzajemne przenikanie struktur otwarcia, że w pewnym przynajmniej zakresie jest możliwe uprzedmiotowienie ludzi i uczłowieczenie martwych przedmiotów ${ }^{74}$.

W kontekście przedstawionej w filozofii dramatu metafory „spotkania na drodze" szczególnego znaczenia nabiera pytanie: kim jest dla Ja drugi człowiek, jaka stanowi dla niego wartość? Pytanie to przychodzi do Ja poprzez słowo, spojrzenie, wyraz twarzy drugiego:

[Drugi] rości sobie prawo do odpowiedzi. Pierwsza odpowiedzią na pytanie jest świadomość, że trzeba odpowiedzieć. W tym czujemy obecność innego człowieka. Inny człowiek jest obecny przy mnie poprzez to, co trzeba, abym dla niego uczynił; i ja jestem przy nim obecny poprzez to, co trzeba, aby on uczynił dla mnie ${ }^{75}$.

To właśnie „roszczenie” konstytuuje dialog, spotkanie. W ten sposób powstaje zobowiązanie, czyli wiązanie obowiązkiem między Pytającym a Odpowiadającym. Tak więc „zobowiązania rodzą się w spotkaniu" 76 .

73 Ibidem, s. 8.

74 J. Tischner, Filozofia dramatu..., s. 17.

75 Ibidem, s. 18.

76 Ibidem. 
Szczególnie ważne dla zrozumienia dialogicznej relacji zobowiązania jest tak zwane zaplecze, rozumiane jako przeżyta przeszłość. Przypadkowość spotkania wydaje się tylko pozorem:

[Gdy nastapi spotkanie] okazuje się, że było przygotowane przez całą przeszłość osób, które się spotkały. Widać wówczas, jak istotną rolę we wzajemnym naprzeciw siebie odgrywa to, co ludzie maja już poza soba ${ }^{77}$.

Z myślenia aksjologicznego, gdy spotkanie dobiega końca, wyłania się, wraz $z$ nadzieją zrozumienia, projekcja wydarzenia, które pozwoli przezwyciężyć tragedię przychodząca $z$ drugim. Przypadek (a może nie przypadek), że drugi staje właśnie w tym miejscu i w tym czasie oraz stawia pytanie o drogę, które należy do najbardziej przejmujących i zajmujacych człowieka:

Ten tylko, kto doświadczył spotkania, może mówić, że doświadczył źródłowo jakiegoś konkretnego dobra i zła, jakiejś tragiczności, jakiejś wolności oraz głosu imperatywu kategorycznego, który od drugiego doszedł ku niemu ${ }^{78}$.

\section{„Drugi" a wartości}

Tym, co wspólne dla uczestników spotkania jest, oprócz sceny, płaszczyzna podzielanych przez ludzi idei i wartości „czyli strefa tego, co znajduje się ponad nami i po czym nigdy nie można deptać"79. Ta strefa ustanawia przed ludźmi nowy świat - „świat spraw ważnych i nieważnych, chwil doniosłych i błahych, czasów świętych i czasów powszednich - słowem: ustanawia hierarchię"80. Uczestnicy spotkania wchodza w dialog, wychodząc $z$ wnętrza hierarchii, czyli idei i wartości. Wzajemne doświadczenie hierarchii jest owocne tylko wówczas, gdy jest ona podobna bądź gdy uczestnicy wykazuja zdolność upodobnienia się do siebie.

\footnotetext{
Ibidem.

78 J. Tischner, Myślenie według wartości..., s. 535-536.

79 J. Tischner, Filozofia dramatu..., s. 18.

80 Ibidem, s. 19.
} 
Na świat międzyludzki przemożny wpływ wywiera etyka, która jest, jak uważa Tischner, „teorią doświadczenia drugiego człowieka, a zarazem doświadczenia samego siebie $\mathrm{w}$ świetle wynikajacym $z$ obecności drugiego" ${ }^{81}$.Tak naprawdę, jak stwierdza krakowski filozof, to:

Nie wiemy dokładnie, czym jest zło ani czym jest dobro - wiemy jedno: zło sprawia, że człowiek staje się istnieniem nieusprawiedliwionym, a dobro sprawia, że istnieje istnieniem usprawiedliwionym. Dobro i zło stanowia prawdziwa metafizykę istnienia ludzkiego, sa tym, czym jest meta-ta-physica ${ }^{82}$.

Należy jednocześnie przyjąć, że kreatorem doświadczenia i zła, i dobra jest sam człowiek. To on bowiem jest panem swych aksjologicznych uznań:

Drugi poszukuje dla siebie ethosu. Ja także poszukuję właściwego dla siebie ethosu. W spotkaniu $z$ drugim nasze poszukiwania albo się rozmina, albo się odnajdą. Jeżeli odnajdziemy się nawzajem, on stanie się pełnym człowiekiem dzięki mnie i ja stanę się pełnym człowiekiem dzięki niemu ${ }^{83}$.

Osobowe wzrastanie nie dzieje się $\mathrm{w}$ pojedynkę, ale $z$ drugim i w relacji do drugiego. Myślenie według wartości o drugim zostało osadzone u Tischnera w przestrzeni aksjologii, ukierunkowanej agatologicznie. Jak stwierdza:

Nie można być sobą poza Dobrem ${ }^{84}$.

Umiejscowienie człowieka w horyzoncie dobra i zła sprawia, że scena dramatu, na której człowiek gra istotę dramatyczna, tak naprawdę może być wszędzie. Sceną rządzą prawa dramatu ludzkiego, a nie prawa samej sceny. Co oznacza „prawdziwie czy nieprawdziwie, że zguba lub ocalenie sa w rękach człowieka" ${ }^{\text {. }}$. Cały ten opis

\footnotetext{
${ }_{81}$ J. Tischner, Etyka wartości i nadziei, w: D. von Hildebrand i in., Wobec wartości, Wydawnictwo „W Drodze”, Poznań 1984, s. 59.

82 J. Tischner, Filozofia dramatu..., s. 193.

83 J. Tischner, Etyka wartości..., s. 62.

84 J. Tischner, W krainie schorowanej wyobraźni, Wydawnictwo Znak, Kraków 1993, s. 75.

85 J. Tischner, Filozofia dramatu..., s. 10.
} 
jest potrzebny po to, aby móc pokazać człowieka jako podmiot zdolny do wierności. Przy czym wolność wyprzedza wierność czy raczej - jest jej warunkiem.

Warto przypomnieć, iż Tischner wyróżnia dwa rodzaje doświadczeń właściwych człowiekowi: doświadczenie agatologiczne i doświadczenie aksjologiczne. Pierwsze jest pierwotne, bardziej podstawowe:

[Doświadczenie agatologiczne] jest przede wszystkim doświadczeniem odsłaniającym, doświadczenie aksjologiczne zaś doświadczeniem projektującym. Doświadczenie agatologiczne dotyczy bycia w świetle dobra, doświadczenie aksjologiczne dotyczy wydarzeń w świetle tego, co wartościowe. Doświadczenie aksjologiczne i płynące stąd myślenie aksjologiczne nastawia się na jeden podstawowy cel - projektowanie wydarzenia, które może zaradzić rozwojowi tragedii. Jako takie zakłada nadzieję, zakłada poczucie siły, zakłada istnienie „zmysłu rzeczywistości”, który odsłania to, jakie wartości są hic et nunc możliwe do zrealizowania ${ }^{86}$.

Doświadczenie aksjologiczne skłania do postawienia pytań: co trzeba zrobić, jak postapić, kogo ocalić, za czym biec, a co porzucić w drodze do drugiego:

Doświadczenie aksjologiczne ciąży ku jakiemuś poświęceniu. Jakiemu? Tego także nie wiemy. Kluczem do aksjologii jest spotkanie $z$ drugim. Dopiero dzięki spotkaniu widzimy ludzi na scenie życia zorganizowanej w hierarchię, preferujemy i rozumiemy preferencje innych. Pozwalamy być. Inni pozwalają nam byćc ${ }^{87}$.

Postawę tę cechuje dążenie do dialogu na równych prawach, bez dominacji i manipulacji. Chodzi w niej głównie o to, aby:

[...] nie dobijać żadnym słowem, żadnym czynem, ani ucieczka, ani zuchwałościa, by nagiąć istnienie ku przeczuwalnej dobroci, a dobroć ku istnieniu, ku trwaniu ${ }^{88}$.

86 J. Tischner, Myślenie według wartości..., s. 537-538.

87 Ibidem, s. 536.

88 Ibidem, s. 535. 
Spotkanie $z$ drugim jest dla Tischnera podstawowym źródłem wszystkich przeżyć aksjologicznych, $z$ przė̇yciem myślenia włącznie ${ }^{89}$ :

Spotkany inny i ja wraz z nim znajdujemy się w przestrzeni, w której coś jest lepsze, coś gorsze, dobre lub złe. Przestrzeń ta nie jest zwykła przestrzenia geometrii Euklidesa, lecz przestrzenia hierarchiczną. Dobro zwie sie po grecku agaton. Logos znaczy to, co rozumne, madre. Powiemy więc: spotkanie jest otwarciem agatologicznego horyzontu doświadczenia międzyludzkiego. Horyzont agatologiczny to taki horyzont, w którym wszystkimi przejawami innego i moimi włada swoisty logos - logos dobra i zła, tego, co lepsze i co gorsze, wzlotu i upadku, zwycięstwa i przegranej, zbawienia i potępienia. Na czym to polega? Tego przy spotkaniu jeszcze nie wiem. Wiem jednak, że gdy spotkam, zawsze o coś takiego chodzi ${ }^{90}$.

Jak zauważa Anna Siwek:

Wartości i dobro stanowia sens spotkania - widząc drugiego, uświadamiamy sobie ich istnienie, a zarazem doświadczamy naszego $z$ nimi zwiąk $\mathrm{u}^{91}$.

Jednocześnie podkreśla, że:

[...] za sprawa spotkania człowiek odkrywa, że nie żyje w świecie, w którym dobro stanowi trwały element, chociaż jest fundamentalnym punktem odniesienia. Chodzi tutaj zarówno o dobro jako cechę samego świata, jak i dobro rozumiane jako wartość człowieka ${ }^{92}$.

Drugi jest przede wszystkim po to, żeby mnie potwierdzić w mojej wolności. Bez drugiego nie ma przejścia od możliwości do faktyczności (na przykład co z tego, że mogę być wierny, jeśli nie mam komu).

Nie chodzi o to, o co pytamy, ale - że pytamy. [...] W każdym pytaniu jest próba przeniesienia się ze świata jednego człowieka w świat drugiego ${ }^{93}$.

[...] jedynie drugi może mnie zapytać o to, co widzę. I to pytanie uświadamia $\mathrm{mi}$, że istnieje obok mnie inny świat - to, co on widzi i czego doświadcza" ${ }^{\prime 4}$.

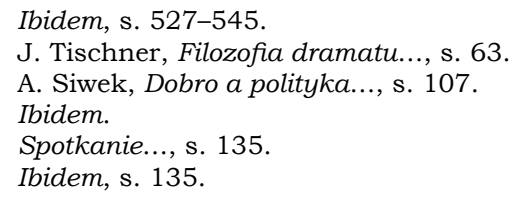


[Jeśli uchwyci się to] w jego niezafałszowanym przez technikę rdzeniu, jest [to] doświadczeniem par excellence etycznym. Tak jak jesteśmy zdolni doświadczyć drugiego, nie jesteśmy zdolni doświadczyć niczego, żadnej rzeczy, żadnego przedmiotu, żadnego krajobrazu ani żadnego zwierzęcia ${ }^{95}$.

Uczestniczenie w hierarchii - czyli porządku wartości - wywiera wpływ na dynamikę dialogu Ja $z$ Ty, który może być głębszy lub płytszy „bliższy temu, co wyżej lub temu, co niżej, bliższy temu, co bardziej wiąże się $z$ działaniem lub co raczej sprzyja powstrzymaniu się od działania"96. Tischner przestrzega, że:

Jeśli ktoś zezwoli na to, by stępiła się w nim wrażliwość na drugiego człowieka, cała jego moralność i całe myślenie etyczne zawisną w próżni ${ }^{97}$.

\section{Jak trafnie zauważa:}

Pierwotnym źródłem doświadczenia etycznego nie jest przeżycie wartości jako takich, lecz odkrycie, że obok nas pojawił się drugi człowiek. [...] To nie wartości, to nie normy, nie przykazania sa „pierwsze”, ale obecność drugiego człowieka ${ }^{98}$.

Początkowo, nawiązując wprost do Romana Ingardena, krakowski filozof uważał, że osoba jest odpowiedzialna za wartości, następnie - w dużym stopniu pod wpływem Emmanuela Lévinasa oraz w duchu swojej filozofii dialogu i filozofii dramatu - głosił, że człowiek jest odpowiedzialny nie za jakieś abstrakcyjne wartości, ale za drugiego człowieka, a za wartości o tyle, o ile wiążą się one $z$ innym ${ }^{99}$. Człowiek zyskuje więc uzasadnienie przez drugiego, „buduje siebie poprzez kolejne wybory, w których "traci i odzyskuje» siebie" $^{100}$. Sens tego działania tkwi w tym, żeby:

\footnotetext{
J. Tischner, Myślenie według wartości..., s. 399.

J. Tischner, Filozofia dramatu..., s. 19.

J. Tischner, Myślenie według wartości..., s. 399.

98 J. Tischner, Etyka wartości..., s. 88.

99 Zob. J. Galarowicz, Paradoks egzystencji etycznej..., s. 319.

100 J. Tischner, Zarys filozofii człowieka..., s. 12.
} 
[...] człowiek z osoby, jaka jest przez swoją naturę, przekształcił się w osobowość, to znaczy, by doszedł do pełnego rozkwitu w swych władzach duchowych i cielesnych ${ }^{101}$.

Po prostu - aby stawał się bardziej człowiekiem w relacjach międzyosobowych.

Człowiek, jak podkreśla Tischner, potwierdza się w tym, czym naprawdę jest:

[...] w imię prawdy, w imię dobra i piękna. Na tym polega znaczenie wzajemności: potwierdzając drugiego, człowiek potwierdza siebie ${ }^{102}$.

Do drugiego, zdaniem Tischnera, trzeba mówić tak, jak głosił ideał romantyków:

[...] przenieść się do środka drugiego i mówić tak, by ten drugi miał świadomość, że to on mówi ${ }^{103}$.

W relacjach $z$ drugim krakowski filozof opowiadał się za metoda sokratejską, w myśl której należy:

[...] rodzić w innych to, co się w nich poczęło. [...] nie jest ważne, kto mówi. Słowo jest tu pomostem do drugiego i do rzeczywistości. Potem zostawia się już sam na sam drugiego i słowo - i ono działa ${ }^{104}$.

Myślenie na poziomie aksjologicznym, zdaniem Tischnera, dąży do tego, żeby:

[...] odróżnić prawdę od nieprawdy. Prawda to idealna wartość tego myślenia. Aby rozpoznać prawdę, aby zrozumieć spotkanego człowieka, trzeba mu pozwolić być, trzeba wejść z nim w dialog, zapytać, co myśli, szukać odpowiedzi, gdy on zada pytanie ${ }^{105}$.

Podkreślić więc trzeba bezsprzecznie, że:

${ }^{101}$ J. Tischner, Jak żyć, Wydawnictwo TUM, Wrocław 2000, s. 9.

102 Spotkanie..., s. 144.

${ }_{103}$ Ibidem, s. 145.

${ }^{104}$ Ibidem, s. 145-146.

${ }^{105} \mathrm{~J}$. Tischner, Myślenie według wartości..., s. 540. 
[...] źródłowych doświadczeń prawdy należy [...] szukać w spotkaniu $z$ drugim człowiekiem $[\ldots]^{106}$.

Właśnie dzięki prawdzie:

[...] wyłania się istotowe w przebiegu spotkania, a potem także dla całego procesu obcowania człowieka $z$ człowiekiem - rozróżnienie między ludzka gra, ułuda, fantomem a ludzka twarza, czyli - nawiązując do greckiego sposobu mówienia - „ikoną” drugiego. Fantom jest maską człowieka, ikona jest jego twarzą ${ }^{107}$.

Człowiek może nakładać różne maski, może udawać i odgrywać zróżnicowane role w zależności od sytuacji. Szczególnie interesująca jest granica, która przebiega między maską a twarzą. Do jej wytyczenia konieczny jest dialog:

Dialog nie tylko rozprasza międzyludzkie złudzenia, lecz również otwiera możliwość rozproszenia złudzeń rzeczowych. Dialog rodzi ideę obiektywi$z m u, z$ idei obiektywizmu bierze się nauka o obiektywnym świecie ${ }^{108}$.

Należy przez to rozumieć, że:

[doświadczenie] drugiego człowieka w jego tragiczności otwiera nasza świadomość na świat obiektywnego dobra i zła, obiektywnych wartości i antywartości - obiektywnych, bo wkorzenionych w realne ludzkie tragedie ${ }^{109}$.

Wierność drugiego i wierność drugiemu polegaja także na tym, co niesie uczucie zawodu, że się:

[...] wystawia na próbę, że nie da się wykluczyć elementu niepewności. Tylko głupi może czuć się absolutnie pewnym, że ma drugiego ${ }^{110}$.

Taka jest natura wartości, które:

[...] rzeźbiąc międzyludzka przestrzeń, zarazem otwierają i zamykają człowieka przed drugim człowiekiem ${ }^{111}$.

${ }^{106}$ Ibidem, s. 541.

107 Ibidem.

108 Ibidem.

${ }^{109}$ Ibidem, s. 404.

110 Spotkanie..., s. 152.

${ }^{111}$ J. Tischner, Filozofia dramatu..., s. 271. 
Jak pisze Władysław Stróżewski, w otwarciu zarówno na drugiego człowieka, jak i na scenę dramatu oraz na przepływający czas nie pozostaje człowiekowi nic więcej niż pokochać ulotność:

Człowiek jest jedyną istota, która jest bytem wśród bytów, a równocześnie sam byt przekracza. [...] Po odkryciach fenomenologii, po ukazaniu absolutności czystej świadomości i ja transcendentalnego, mówić, że jesteśmy zwyczajnym bytem? A jednak jest to prawda. Tak samo jak prawda jest, że tę sytuację potrafimy przekroczyćc ${ }^{112}$.

Tischner stwierdza, że doświadczając drugiego poprzez wartości:

[...] wiemy w sposób pewny: drugi jest, jest inny, jest transcendentny. Wiemy również coś więcej: on i ja znajdujemy się w przestrzeni dobra i zła, wartości i antywartości. Moge dotknąć drugiego, skrzywdzić go, mogę mu przynieść radość. Podobnie on ${ }^{113}$.

Należy więc - za krakowskim filozofem - wyraźnie podkreślić, że:

[Drugi, którego] spotykamy we wnętrzu horyzontu agatologicznego nie jest ani zwycięskim dobrem, ani zwycięskim złem. Jest tym, w kim dobro zostało wystawione na działanie $\mathrm{zła}^{114}$.

Na widok tragedii przychodzącej $z$ drugim otwiera się możliwość jakiegoś poświęcenia, do którego zdolna jest osoba o mocnej strukturze egologicznej: „Pozwalając drugiemu być” jednocześnie umacnia siebie, rezygnując $z$ potrzeby posiadania innego:

Pozwalając być innemu, doświadczamy dobra własnej wolności i w tym przeżyciu głębiej „mamy siebie”. Na tym zasadza się idea wspaniałomyślności. Dopiero we wspaniałomyślności człowiek staje się soba, a wolność wolnością ${ }^{115}$.

W tym miejscu Tischner odwołuje się do poglądów wielu fenomenologów, zwłaszcza Romana Ingardena, którzy podkreślali, iż „w posta-

${ }_{112}$ W. Stróżewski, Istnienie i dobro, w: Pytajac o człowieka..., s. 15.

$113 \mathrm{~J}$. Tischner, Myślenie według wartości..., s. 533.

114 J. Tischner, Filozofia dramatu..., s. 68.

115 J. Tischner, Spór o istnienie..., s. 334. 
wie realizacji wartości obowiąuje człowieka wspaniałomyślność"116. Jest to postawa, jak pisze Jan Galarowicz, „pozwalajaca ludziom, wartościom i rzeczom być, to zdolność uznania w nich tego, czym sa i oddania im sprawiedliwości"117. A więc - co podkreśla Tischner „uznania innego jako innego, czyli oddania innemu tego, co «jego jest"”"118.

Można również cofnąc się przed drugim:

[...] uciec, zająć postawę agresji, zrezygnować z myślenia. Móc się cofnąć albo podjąc spotkanie - to uświadomić sobie wolność. Spotkanie nie wymusza niczego, zwłaszcza myślenia, ono tylko daje do myślenia. Podjęte myślenie jest zakładaniem i potwierdzaniem wolności ${ }^{119}$.

Tischner dostrzega w człowieku „wewnętrzna przestrzeń świadomości" ${ }^{120}$. Twierdzi, że to właśnie agatologiczna przestrzeń świadomości jest „warunkiem możliwości człowieczeństwa człowieka jego bycia soba jako człowieka"121. Pokazując człowieka jako istotę zanurzona w przestrzeni agatologicznej, krakowski filozof wykorzystuje metaforę narodzin:

W przypadku bycia soba i człowieczeństwa nie jest bowiem tak, że bycie sobą rodzi się samo, lecz tak, że nie można być soba, jeśli się tego nie chce. Paradoks człowieka na tym polega, że $z$ jednej strony „już się narodził" (został „zrodzony”), a $z$ drugiej - „sam rodzi siebie”. Na podstawie dotychczasowych analiz wiemy: „rodzi siebie” w przestrzeni agatologicznej i dzięki niej. Ona jest jego przestrzenią macierzysta, jego matrix ${ }^{122}$.

Istotą struktury człowieka w ujęciu Tischnera jest zatem świadomość agatologiczna:

Trzeba jednak dopowiedzieć, iż świadomość ta nie jest świadomościa rozwijająca się jedynie wewnątrz ludzkiego umysłu. Agatologia tkwiąca

116 J. Tischner, Myślenie według wartości..., s. 49.

117 J. Galarowicz, Paradoks egzystencji etycznej..., s. 332.

118 J. Tischner, Inny..., s. 28.

119 J. Tischner, Myślenie według wartości.., s. 539.

120 J. Tischner, Spór o istnienie..., s. 277.

${ }^{121}$ Ibidem, s. 280.

122 Ibidem. 
w człowieku byłaby pusta, bezużyteczna, gdyby nie otwarcie człowieka na drugiego, innego. W strukturze ludzkiej jest obecne ukierunkowanie poza samego siebie ${ }^{123}$.

Jak to ujmuje Anna Siwek, być soba, to - według Tischnera istnieć jako człowiek w zapośredniczeniu wobec drugiego człowieka. Natomiast realizować dobro - co jest istota człowieczeństwa - to realizować je w rozmaitych relacjach $z$ drugim człowiekiem ${ }^{124}$. Skłania to do konstatacji, że tym, co konstytuuje człowieczeństwo, jest relacja wzajemności. Tym, na co przede wszystkim należy zwrócić uwagę, jest fakt, iż:

[...] podstawowym doświadczeniem osobowym i zarazem warunkiem genezy konstytutywnej Ja w jego „byciu - soba” jest doświadczenie innego ${ }^{125}$.

Dobro ustanawia świat ludzkich relacji poza regułami rządzącymi bytem:

Trzeba powiedzieć: Dobro „rodzi” dobroć, dobroć „prowokuje” Dobro, by było jeszcze bardziej dobre. Zarówno „rodzenie” jak i „prowokacja” maja znaczenie „łaski”. Nic nie dzieje się z przymusu, lecz wszystko z wolności. Wszystko jest „darmo dane” - zarówno ofiara, jak przyjęcie ofiary ${ }^{126}$.

W ten sposób Tischner wprowadza do opisu relacji międzyludzkich pojęcie łaski, które stanie się dla niego drogowskazem prowadzacym do drugiego człowieka.

Krakowski filozof stoi na stanowisku, że ucieczka od drugiego oznacza odrzucenie najcenniejszego daru, jaki posiada człowiek wolności. Otwierając się na drugiego i podejmując $z$ nim dialog, na powrót tę wolność odzyskujemy. Poprzez dialog człowiek otwiera się i wychodzi $z$ kryjówki:

Trzeba się wychylić, przekroczyć próg, wyciagnać rękę, znaleźć wspólne miejsce do rozmowy. Miejsce to nie będzie już kryjówka, w której człowiek

${ }^{123}$ A. Siwek, Dobro a polityka..., s. 113.

${ }^{124}$ Ibidem.

125 J. Tischner, Spór o istnienie..., s. 221.

${ }^{126}$ Ibidem, s. 262. 
pozostaje sam ze swoim lękiem, lecz miejscem spotkania, zaczątkiem jakiejś wspólnoty, być może początkiem domu ${ }^{127}$.

[Wchodząc w dialog] oczekuję, iż drugi uzna we mnie to, kim jestem, jak również uwierzy, że ja także jestem gotów uznać w nim to, kim on jest. Relacja wzajemnego uznania stwarza możliwości wzajemnego rozumienia ${ }^{128}$.

Człowiek nie wystarcza sobie samemu, potrzebuje potwierdzenia i uznania ze strony drugiego. Ja aksjologiczne nie potrafi osiagnać pełni swojej wartości, „nie zna [ono] uczucia nasycenia, uczucia pełni, uczucia rozkwitu Ja"129. Można nawet przyjąć, że gdyby nie było drugiego, to, jak pisał Władysław Zuziak, należałoby go, na potrzeby Ja, wymyślić ${ }^{130}$, albowiem:

Spotykając, wiem, że inny człowiek jest i że jest wobec mnie taki, jaki naprawde jest, bez masek i bez zasłon. [...] od momentu spotkania życie moje nabrało nowego znaczenia, a otaczajacy mnie świat uzyskał nowa zasadę organizacji. Przeżycie spotkania jest nie tylko szczytowym rodzajem doświadczenia innego człowieka, ale również szczytem doświadczeń w ogóle $e^{131}$.

Można zatem na koniec przyjąć, że „błądzenie w żywiole dobra” i wartości ostatecznie porządkuje spotkanie $z$ drugim.

\section{Podsumowanie}

Reasumując, należy zauważyć, że w filozofii Józefa Tischnera pierwotnym stanem człowieka jest zniewolenie, a nie wolność. Dopiero dzięki spotkaniu $z$ drugim może on się wydobyć $z$ kryjówki. Drugi rozbudza w człowieku nadzieję na wolność oraz wiarę w wol-

\footnotetext{
127 J. Tischner, Etyka solidarności, Wydawnictwo Znak, Kraków 2000, s. 17.

128 J. Tischner, Filozofia dramatu..., s. 275.

129 J. Tischner, Świat ludzkiej nadziei, Wydawnictwo Znak, Kraków 2005, s. 165.

${ }_{130}$ W. Zuziak, Ja - Ty - On. Dojrzewanie do Boga poprzez dialog, w: Między potepieniem a zbawieniem. Myślenie religijne Józefa Tischnera, red. J. Jagiełło, W. Zuziak, Wydawnictwo Znak, Kraków 2004, s. 117.

${ }^{131}$ J. Tischner, Filozofia dramatu..., s. 174.
} 
ność, co jest początkiem wyzwolenia, otwarcia na dobro i wartości. Można przyjąć, że właściwościa myśli Tischnera jest jej integralność: wartości łączą się i do siebie odnoszą. To wartości skierowuja nas na drugiego. Poprzez uczestnictwo w samych wartościach możliwe staje się więc spotkanie $z$ drugim.

Tischner kwestionuje człowieka w jego człowieczeństwie, ale nie pogrą̇a. Daje nadzieję na wyjście ze zniewolenia. Tischnerowskie myślenie według wartości o drugim zmusza do wysiłku zmiany. Stawia wierność drugiemu człowiekowi przed wiernością zasadom. Myśl Tischnera wydaje się nie tylko efektowna, ale także praktyczna. Wartości staja się absurdalne, gdy „odrywaja się” od człowieka. Myśliciel wzywa więc do stałego weryfikowania wartości oraz do gotowości do wzniesienia się ponad rutynę życia wówczas, gdy „trzeba” dopełnić powinności, podjąć wysiłek spotkania $z$ drugim i wziąć za niego odpowiedzialność. Należy zatem wierzyć sobie i uwierzyć drugiemu.

\section{Bibliografia}

Człowiek jest istota dramatyczna. Rozmowa z ks. prof. Józefem Tischnerem, w: C. Wodziński, Filozofia jako sztuka myślenia, Wydawnictwo Prószyński i S-ka, Warszawa 2000.

Galarowicz J., Paradoks egzystencji etycznej. Inspiracje: Ingarden -

Wojtyła - Tischner, Wydawnictwo Naukowe Papieskiej Akademii Teologicznej, Kraków 2009.

Kępiński A., Psychopatie, Wydawnictwo Literackie, Warszawa 2013.

Kot D., Posłowie, w: J. Tischner, Inny. Eseje o spotkaniu, Wydawnictwo Znak, Kraków 2017.

Kuderowicz Z., Józef Tischner-jako filozof $i$ etyk, w: Filozofia XX wie$k u$, t. 1, red. Z. Kuderowicz, Wiedza Powszechna, Warszawa 2002. Lévinas E., Całość i nieskończoność. Esej o zewnętrzności, Wydawnictwo Naukowe PWN, Warszawa 1998.

Siwek A., Dobro a polityka. Platon i Tischner. Dwie filozofie dobra, Instytut Studiów Politycznych Polskiej Akademii Nauk, Warszawa 2014. 
Skarga B., Człowiek agatologiczny, w: Pytajac o człowieka. Myśl filozoficzna Józefa Tischnera, red. W. Zuziak, Wydawnictwo Znak, Kraków 2002.

Skarga B., Emmanuel Lévinas - metafizyka jako etyka, w: Filozofia $X X$ wieku, t. 1, red. Z. Kuderowicz, Wiedza powszechna, Warszawa 2002.

Spotkanie. $Z$ ks. Józefem Tischnerem rozmawia Anna Karoń-Ostrowska, Wydawnictwo Znak, Kraków 2003.

Stawrowski Z., Między miłością a sprawiedliwościa, „Logos i Ethos” 2001, nr 1(10).

Stróżewski W., Istnienie i dobro, w: Pytając o człowieka. Myśl filozoficzna Józefa Tischnera, red. W. Zuziak, Wydawnictwpo Znak, Kraków 2002.

Szary S., Człowiek - podmiot dramatu. Antropologiczne aspekty filozofii dramatu Józefa Tischnera, Wydawnictwo Antyk, Kęty 2005.

Tarnowski K., „Myślenie według wartości” Józefa Tischnera, „Znak” 1985, nr 12 (373).

Tischner J., Etyka solidarności, Wydawnictwo Znak, Kraków 2000.

Tischner J., Etyka wartości i nadziei, w: Wobec wartości, red. D. von Hildebrand i in., Wobec wartości, Wydawnictwo „W Drodze”, Poznań 1984.

Tischner J., Fenomenologia spotkania, „Analecta Cracoviensia” 1978.

Tischner J., Filozofia dramatu, Wydawnictwo Znak, Kraków 1999.

Tischner J., Inny. Eseje o spotkaniu, Wydawnictwo Znak, Kraków 2017.

Tischner J., Jak żyć, Wydawnictwo TUM, Wrocław 2000.

Tischner J., Myślenie w żywiole piękna, Wydawnictwo Znak, Kraków 2004.

Tischner J., Myślenie według wartości, Wydawnictwo Znak, Kraków 2011.

Tischner J., Spór o istnienie człowieka, Wydawnictwo Znak, Kraków 1998.

Tischner J., Świat ludzkiej nadziei, Wydawnictwo Znak, Kraków 2005. Tischner J., W krainie schorowanej wyobraźni, Wydawnictwo Znak, Kraków 1993.

Tischner J., Zarys filozofii człowieka: dla duszpasterzy $i$ artystów, Wydawnictwo Naukowe Papieskiej Akademii Teologicznej, Kraków 1991. 
Tischner J., Zło $w$ dialogu kuszenia, „Znak” 1982, nr 3 (328).

Tischner J., Żakowski J., Tischner czyta Katechizm, Wydawnictwo Znak, Kraków 2000.

Zuziak W., Ja - Ty - On. Dojrzewanie do Boga poprzez dialog, w: Między potępieniem a zbawieniem. Myślenie religijne Józefa Tischnera, red. J. Jagiełło, W. Zuziak, Wydawnictwo Znak, Kraków 2004.

\section{Thinking According to the Value of "The Other" in the Philosophy of Józef Tischner}

Man and specifically human experiences define the space of Józef Tischner's philosophy. The main thread of thinking about man is "the experience of the other" through which is born the "I", the subject of Tischner's philosophy of drama, in which fundamental issue is the meeting. Contemporary man, usually locked in his narrative of monadic life, is wary of the other. However, personal growth does not happen alone, but with the other. Man is not enough for himself, he needs confirmation and recognition of the other. From the meeting with the other begins a drama which cannot be predicted. Through the drama that happens between „I" and you, the participants are open to the world of values and the agathological and axiological horizon of existence is before them. From the other, as Tischner notes, a call is coming to save him. By axiological thinking, one should try to solve the problem of the tragedy of the situation in which the other was found. This is thinking about the other according to value. The primacy of good over evil is revealed in the recognition of human freedom which is the essence of the relationship with the other.

Keywords: Józef Tischner, human, meeting, "the other", values. 